\title{
IMPACT OF ARTIFICIAL STRUCTURES ON BIODIVERSITY OF ESTUARIES: A CASE STUDY FROM COCHIN ESTUARY WITH EMPHASIS ON CLAM BEDS
}

\author{
A.U.ARUN \\ e-mail: arunkurup@hotmail.com

\begin{abstract}
Department of Marine Biology, Microbiology and Biochemistry, School of Marine Sciences, Cochin University of Science and Technology, Cochin 682016 , National Institute of Oceanography, Regional Centre, Cochin, Kerala, India
\end{abstract} \\ (Received $18^{\text {th }}$ August 2004, accepted $4^{\text {th }}$ August 2005)
}

\begin{abstract}
Interannual and seasonal variability of the hydrographic parameters and distribution of Villorita sp. in the Cochin estuary was studied to assess the impact due to the construction of Thannermukkom bund. Results showed that periodical closing and opening of the bund had significant effect on different hydrographic parameters. Water temperature showed an increase during January to March and July to September; values showed a decrease from April to June and also during October to December. The study zones had a freshwater dominated environment with measurable salinity occurring only during pre-monsoon and zone south of bund (B) having significantly higher salinity than other. Salinity showed a significant negative correlation with dissolved oxygen $(P<0.05)$ at zone B. All the zones were predominantly acidic. The maximum dissolved oxygen concentration observed was during July. Dissolved oxygen concentration at zone north of bund (A) was higher in magnitude than zone south of bund (B) and at both zones (A and B) dissolved oxygen is highly correlated with most of the parameters $(P<0.05)$. Net productivity at all zones was highly fluctuating and significant differences were observed between zones $(P<0.05)$. Nitrate concentration was maximum during post-monsoon and minimum during pre-monsoon and significant difference between zone A and B $(P<0.05)$ were noted. Nitrite concentration decreased gradually from December to June and increased from July to November at both zones. The maximum phosphate concentration at all the zones was during May and there was no significant difference between zones at 5\% level. At zone A the predominant nature of substratum was silty-sand and at zone B it was sand. In the case of sand, silt and clay there were significant difference between zones; $P<0.01$ for sand and silt; $P<0.05$ for clay. Nearly 85 genera of phytoplanktons could be identified with 20-30 non-identifiable types. Bray-Curtis similarity index for hydrographic parameters of non transformed and fourth root transformed data showed that transformation has only homogenized the data, which resulted in higher similarity between parameters than for non transformed data, but has not changed the linkage pattern. Similar analysis for different months resulted in the formation of three clusters with very high similarity within each cluster. These were: the first cluster representing the period of closure of the bund (December to May), second cluster of opening of the bund (June to November) and the third one of the months in between. This gives a clear-cut difference between closed and opened stages of the bund and leads to the conclusion that periodical opening and closing of bund affects all the hydrographic parameters in similar fashion in each month in every year. It can be concluded that construction, existence and periodical opening and closing of bund at Thannermukkom has been seriously deteriorating the ecology of the cochin estuary especially in the southern part of the bund with respect to clam beds.
\end{abstract}

Keywords. Thannermukkom bund, hydrographic parameters, water temperature, dissolved oxygen, nitrate concentration, phosphate concentration

\section{Introduction}

Over the past few decades, the impact of artificial structures such as dams and bunds upon natural ecosystems such as estuaries and their biodiversity had been one of the principal concerns raised. Though considerable efforts have been made to alleviate 
these impacts, they persist to result in significant negative impacts to the ecosystems and to the people that depend upon them for their living. This paper presents the results of the impacts of Thannermukkom bund (Fig. 1) in Cochin estuary with special emphasis on clam bed.

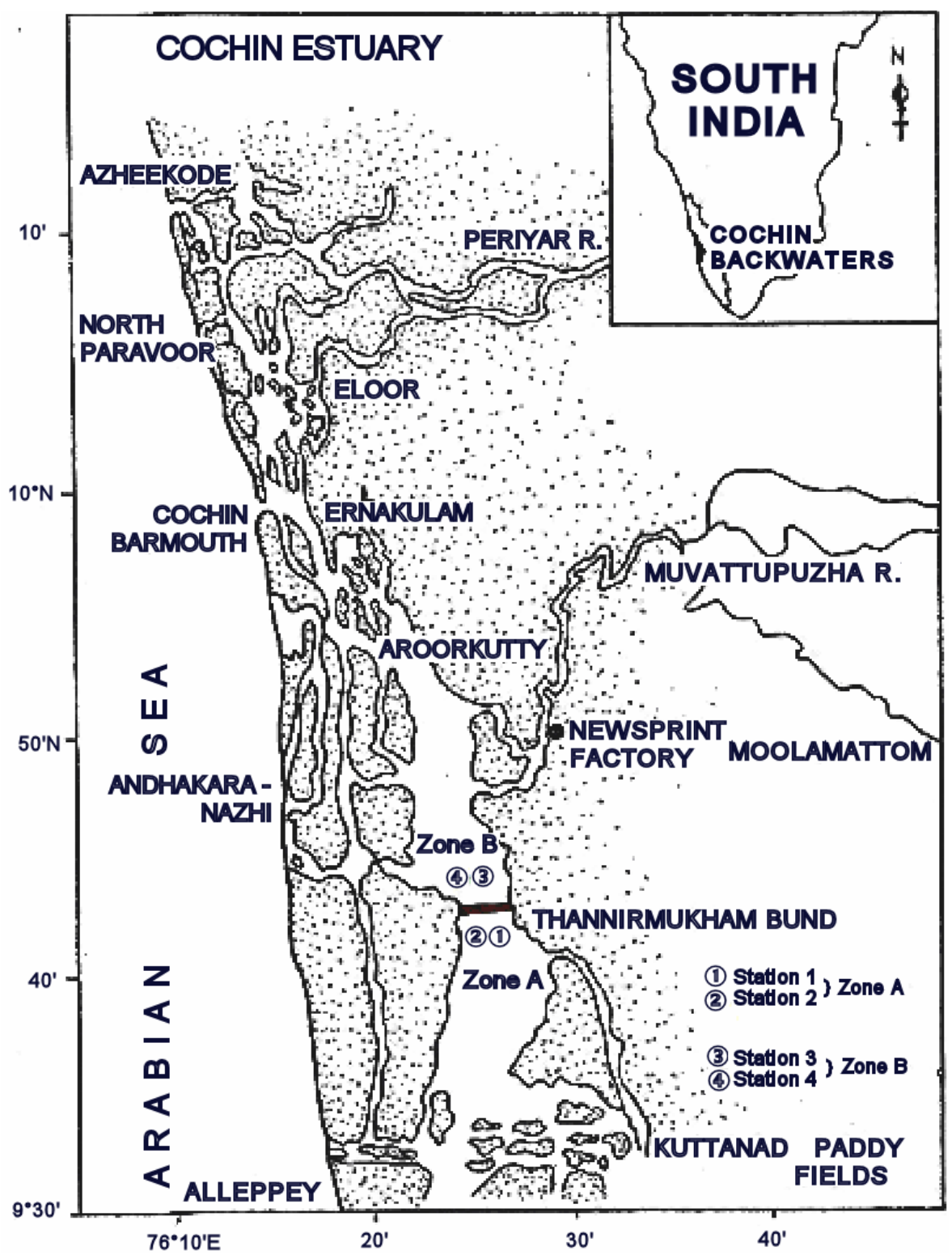

Figure 1. Location and surroundings of the Cochin estuary

Cochin estuary extends from $9^{\circ} 30^{\prime}$ to $10^{\circ} 20^{\prime} \mathrm{N}$ and $76^{\circ} 13^{\prime}$ to $76^{\circ} 5^{\prime} \mathrm{E}$. This estuary is about $100 \mathrm{~km}$ long and 3-4 km wide and is a part of Vembanadu lake, the largest estuary along the west coast of India. Thannermukkom bund was constructed in 1974 to prevent salt-water incursion and to promote cultivation of in the low-lying fields. The bund was made functional in 1976. It remains closed from January to May every year. A number of studies had pointed out the severe environmental impact of the bund on the ecology and fishery of the Cochin estuary $[12,21]$. Drastic ecological changes had been reported in the region, particularly south of the bund, thereby affecting the ecology, distribution, survival and abundance of the living resources in the estuary. This study 
attempts to disclose the exact impact of Thannermukkom bund on the biodiversity of Cochin Estuary with special emphasis on the clam (Villorita $\mathrm{sp}$ ) beds.

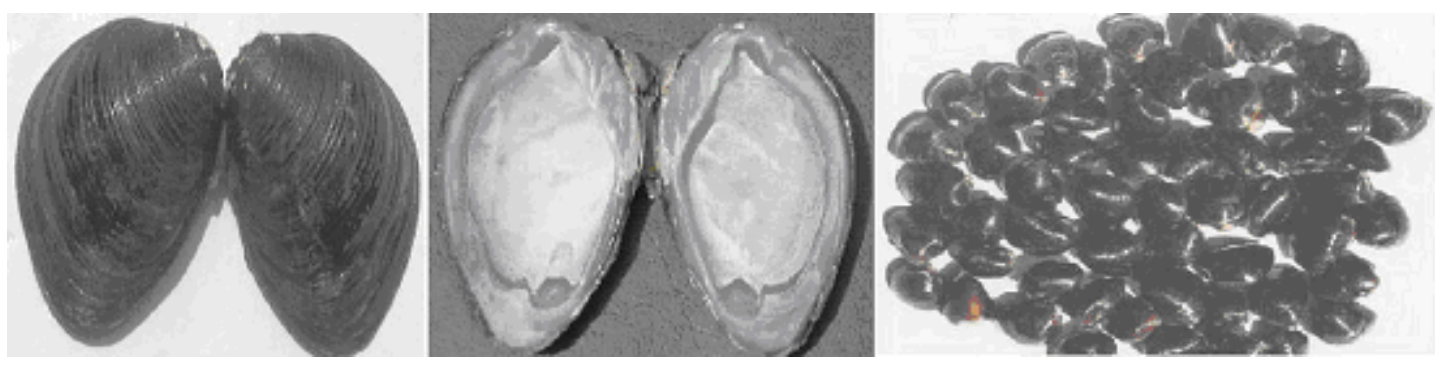

Figure 2. Villorita cyprinoides (generally known as black clam)

Villorita cyprinoides - generally known as black clam (Fig. 2) - is reported to be widely distributed in Cochin estuary [1]. Its bed is generally regarded as an ecosystem in its own rights, because this calcareous biomass (Villorita sp.) traps sediment and provides a structural basis for the growth of many other species such as autotrops and heterotrops. These clams feed by filtering the water column above them and excretions of the community stimulate the nutrient cycle. The shell of clam provides the raw material for the manufacture of cement and lime and the flesh forms a source of pertinacious food for a large section of people inhabiting the coastal areas. Thousands of families are depending on this species for their living. Clam meat is used for human consumption and also as a protein supplement for prawn and poultry feed.

The annual production of clam from the harvest of natural resources from India was estimated as $45412 \mathrm{t}$. The black clam, Villorita cyprinoides tops the clam production forming 67 percent $(29077 \mathrm{t})$ of the total estimated annual production. Major production centers in Kerala are the Vembanad and Ashtamudi lake. Achari (1988) has described the characteristics of clam resources of Vembanad lake and has estimated a total production of 2500 tones of clam. Arun [1] concluded that the total landings of Villorita from Cochin estuary are nearly 1300 tonnes.

\section{Materials and methods}

Sampling was made at four locations in the estuary for the present investigation (Fig. 1). Stations were selected at south and north of Thannermukkom bund for which stations I and II were taken as Zone A and stations III and IV were taken as Zone B. Regularly, at fortnightly intervals sampling was carried out from these zones for a period of two and half years starting from November 1998. Samples were taken from estuarine bottom. All the analysis were carried out by standard procedure, temperature (ordinary thermometer), salinity by Mohr's titration method [23], $\mathrm{pH}$ by $\mathrm{pH}$ meter, DO by Winkler's method [23], productivity by Gaarder and Gran's light and dark bottle method [23], nitrate by Morris \& Riley [20] and Grasshoff [9], nitrate by Bendschreider \& Robinson [2] given by Grasshoff [9], phosphate by Grasshoff [9], silicate by Koroleff [14] given by Grasshoff [9] and sediment composition by Carver [4].

Three ways ANOVA is applied to the data to compare the variations if any, of zones $\mathrm{A}$ and $\mathrm{B}$, between months and between opening and closing stages of the study period for each of the parameters. Bray-Curtis similarity index is calculated between hydrographic parameters (among different parameters, those with $r$ values such that 
$r<0.361$ with all other parameters are deleted from being included in the diagram. Hence the parameters $\mathrm{pH}, \mathrm{N}: \mathrm{P}$ ratio, $\mathrm{NO}_{3}{ }^{-}$and $\mathrm{PO}_{4}{ }^{3-}$ are removed at zone $\mathrm{A}$ and the parameters $\mathrm{pH}, \mathrm{N}: \mathrm{P}$ ratio, $\mathrm{NO}_{3}{ }^{-}$and $\mathrm{PO}_{4}{ }^{3-}$ are removed at zone $\mathrm{B}$ ) and months to group together the parameters and months which are highly correlated. Draughtsman's plot is drawn for studying the relation between different hydrographic characteristics at these locations.

\section{Results and discussion}

Results in general indicated that the hydrographical characteristics of the study zone varied during the study period. Zone $\mathrm{A}$ and zone $\mathrm{B}$ were found to be highly different with respect to all hydrographic parameters except $\mathrm{N}: \mathrm{P}$ ratio, $\mathrm{PO}_{4}{ }^{3-}, \mathrm{SiO}_{3}{ }^{2-}\left(F_{(1,20)}=\right.$ 4.5547, $P<0.05)$. Similarly, month wise difference was highly conspicuous for all the parameters except NPP and GPP $\left(F_{(5,20)}=3.1232, P<0.05\right)$. These results are presented in Table 1.

Further analysis revealed that the temperature fluctuation was $7{ }^{\circ} \mathrm{C}$ at zone A and $4-5{ }^{\circ} \mathrm{C}$ at zone B. Distribution and growth of estuarine organisms especially black clam (Villorita cyprinoides) were found to be inhibited by high temperature fluctuations, i.e., low growth rate and low stock density of clams were observed in zone A to that of zone B. Gradual and small increase in temperature accelerates the growth of Donax sp. [25]. Present investigation do not support the views presented by Kurian [16], i.e., the seasonal variation in bottom temperature of a particular zone in Cochin estuary is only 2-4 ${ }^{\circ} \mathrm{C}$ and so temperature is not an important factor affecting the distribution of fauna in the Cochin backwaters. In Cochin estuary comparatively higher temperature prevailed during pre-monsoon and low temperature during monsoon periods, similar observation was made by Talikhedkar et al. [25], Beninger \& Lucas [3] and Modassir [18] in different estuaries. During monsoon months a sharp decrease in the ambient temperature was noted due to prevailing rain [7, 22]. Zone A has comparatively lower temperature than zone B during pre-monsoon, closing of bund during this period resulted in the stagnation of water body at zone A, which is south of the bund.

Salinity of interstitial water in the mud at few millimetres below the bottom could be almost constant, while the salinity of the overlying water varies back and forth through the tidal range [16]. Zone B showed high salinity fluctuation when compared to zone A $(P>0.001)$ (Fig. 3) especially during pre-monsoon; distinct variation in salinity between zone $\mathrm{A}$ and $\mathrm{B}$ was due to the seasonal infiltration of saline water from the sea and the prevention of tidal flow by the closing of bund during pre-monsoon.

In most of the months the $\mathrm{pH}$ of zones A and B were acidic (Fig. 4), the river water remained acidic throughout the year [26].

Seasonal variation in dissolved oxygen was found to be influenced by the monsoon showers, the maximum DO was during July, which coincides with South-West monsoon (Fig. 4). Similar observation was reported by Modassir [18] in Zuari estuary and Jaybal \& Kalyani [11] in Vellar estuary. It was also noted that a significant negative correlation is exhibited between salinity and dissolved oxygen at zone $\mathrm{B}(P<0.05)$, only at this zone (zone B) variation in salinity has occurred due to the closing of Thanneermukkom bund. Inverse relationship between salinity and DO in Cochin estuary has reported by Haridas et al. [10] and Kumaran \& Rao [15]. Zone A was more productive than others (Figs. 5 and 6 ), this was due to the favourable environmental 
Table 1. Three-way ANOVA for testing significance of difference between parameters $(r=5)$, months $(j=6)$ and stations $(k=2)(\boldsymbol{T} \boldsymbol{F} \boldsymbol{r a}=$ temperature $F$ ratio; $\boldsymbol{S} \boldsymbol{F} \boldsymbol{r a}=$ salinity $F$ ratio; pH $\boldsymbol{F} \boldsymbol{r a}=p H F$ ratio; DOF $\boldsymbol{F} \boldsymbol{a}=$ dissolved oxygen $F$ ratio; $\boldsymbol{N P} \boldsymbol{F} \boldsymbol{r a}=$ net productivity $F$ ratio; $\boldsymbol{G P} \boldsymbol{F} \boldsymbol{r a}=$ gross productivity $F$ ratio; $\boldsymbol{N P} \boldsymbol{r a} \boldsymbol{F}=$ net productivity to gross productivity $F$ ratio; $\mathrm{NO}_{3} \boldsymbol{F} \boldsymbol{r a}=$ nitrate $F$ ratio; $\boldsymbol{O}_{2} \boldsymbol{F}$ ra $=$ nitrite $F$ ratio; $\boldsymbol{P O}_{4} \boldsymbol{F} \boldsymbol{r a}=$ phosphate $F$ ratio; $\mathrm{SiO}_{3} \boldsymbol{F} \boldsymbol{r a}=$ silicate $F$ ratio; $\boldsymbol{S} \boldsymbol{F} \boldsymbol{r a}=$ sand $F$ ratio; $\boldsymbol{S i} \boldsymbol{F} \boldsymbol{r a}=$ silt $F$ ratio; $\boldsymbol{C l} \boldsymbol{F}$ ra $=$ clay $F$ ratio)

\begin{tabular}{ccccccc}
\hline source & $\begin{array}{c}\mathbf{A} \\
\text { (parameters) }\end{array}$ & $\begin{array}{c}\mathbf{B} \\
\text { (months) }\end{array}$ & $\begin{array}{c}\mathbf{C} \\
\text { (stations) }\end{array}$ & $\begin{array}{c}\text { AB inter- } \\
\text { action }\end{array}$ & $\begin{array}{c}\text { BC inter- } \\
\text { action }\end{array}$ & $\begin{array}{c}\text { AC inter- } \\
\text { action }\end{array}$ \\
\hline d.o.f. & 4 & 5 & 1 & 20 & 5 & 4 \\
T F ra & 10.62 & 69.04 & 0.49 & 14462.00 & 4.45 & 0.59 \\
S F ra & 61.00 & 11.13 & 78.83 & 4.39 & 3.73 & 12.84 \\
pH F ra & 4.39 & 4.85 & 4.55 & 0.69 & 0.24 & 0.97 \\
DO F ra & 175.11 & 48.04 & 247.96 & 26.86 & 34.75 & 5.26 \\
NP F ra & 3.85 & 1.12 & 10.92 & 1.11 & 1.24 & 0.39 \\
GP F ra & 4.20 & 2.69 & 25.14 & 5.14 & 0.87 & 0.42 \\
NP ra F & 0.79 & 5.94 & 0.17 & 0.52 & 1.69 & 0.13 \\
NO F ra & 2.09 & 35.51 & 6.01 & 13.16 & 4.49 & 0.44 \\
NO$_{2}$ F ra & 35.95 & 20.53 & 50.30 & 17.05 & 8.42 & 7.11 \\
PO $_{4}$ F ra & 4.35 & 3.12 & 0.19 & 0.60 & 2.68 & 0.26 \\
SiO $_{3}$ F ra & 25.81 & 3.79 & 1.16 & 1.16 & 1.82 & 0.45 \\
S.F ra & 2.36 & 5.45 & 74.39 & 1.20 & 6.18 & 3.28 \\
Si.F ra & 2.50 & 5.37 & 79.56 & 1.14 & 5.83 & 3.05 \\
Cl.F ra & 1.90 & 5.59 & 56.38 & 1.38 & 7.03 & 3.87 \\
\hline
\end{tabular}
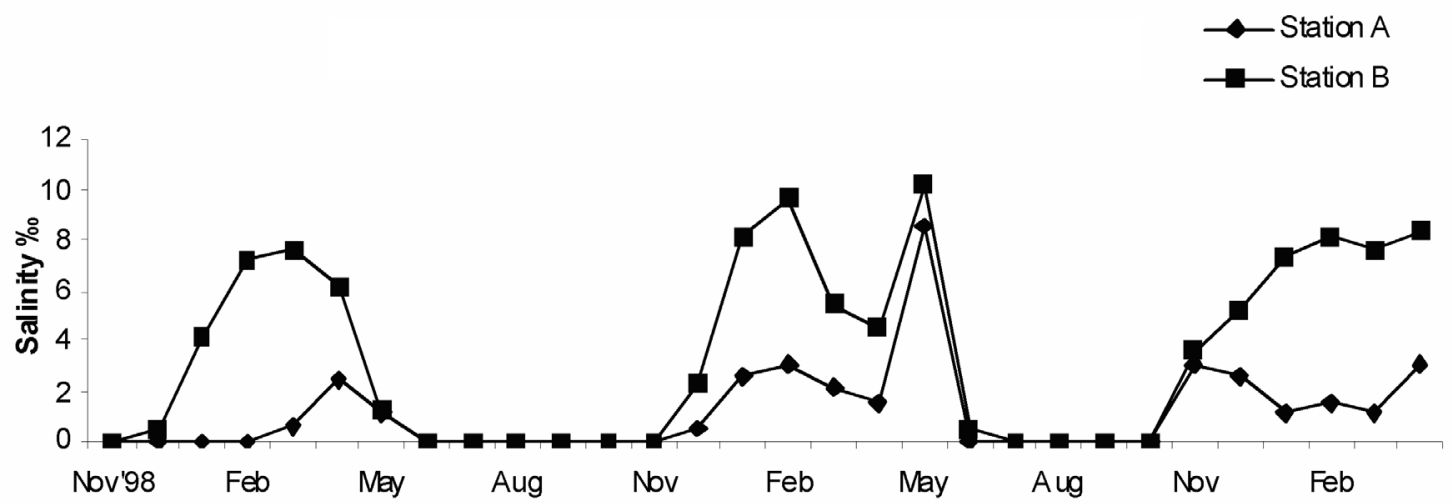

Figure 3. Monthly variation in salinity at station $A$ and $B$

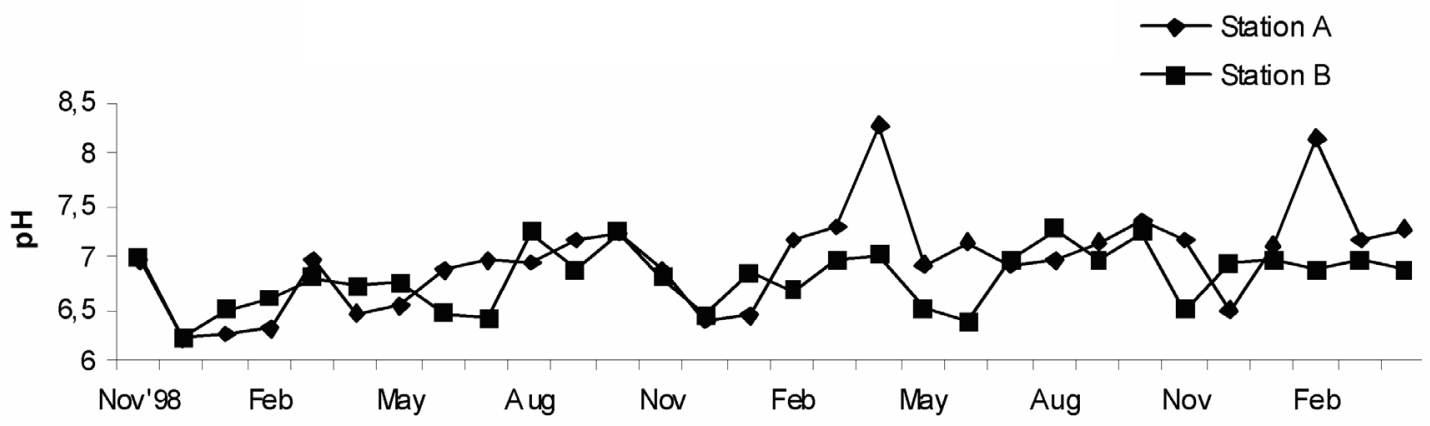

Figure 4. Monthly variation of $p H$ at station $A$ and $B$ 
condition which persisted in that area. At all the zones there was an inverse relationship between temperature and productivity (Figs. 7 and 8). At zone A there was a low net: gross productivity ratio especially in pre-monsoon (Fig. 9), during this period backwater receives a considerable amount of organic matter from land, whose decomposition requires more oxygen, this in turn would enhance the respiration rate which results in low net: gross productivity ratio.

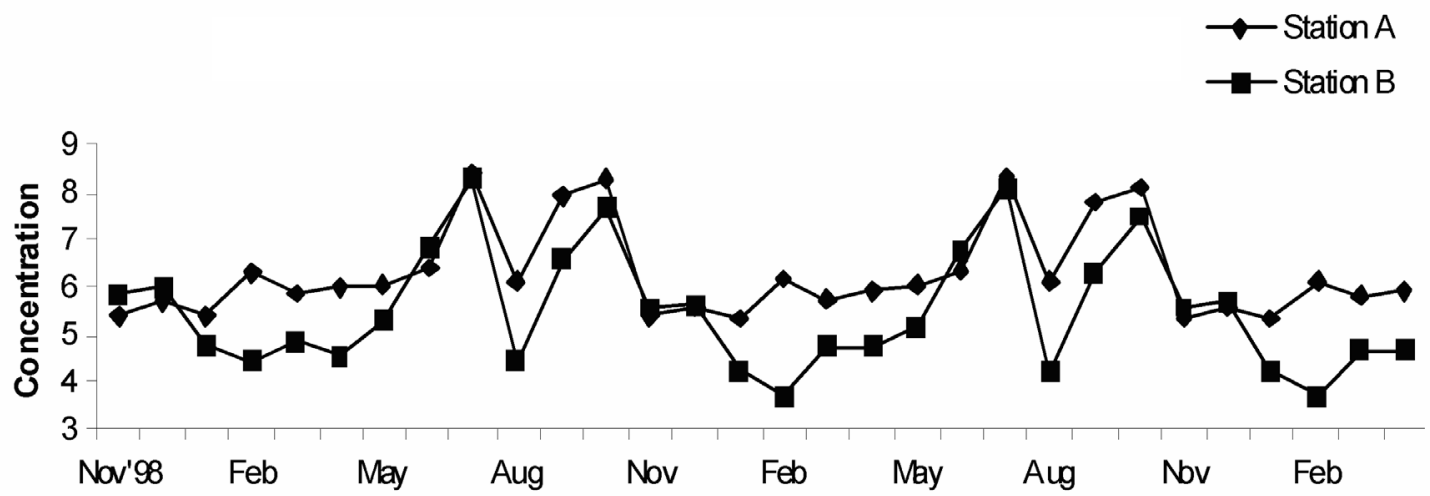

Figure 5. Monthly variation of dissolved oxygen at station $A$ and $B$

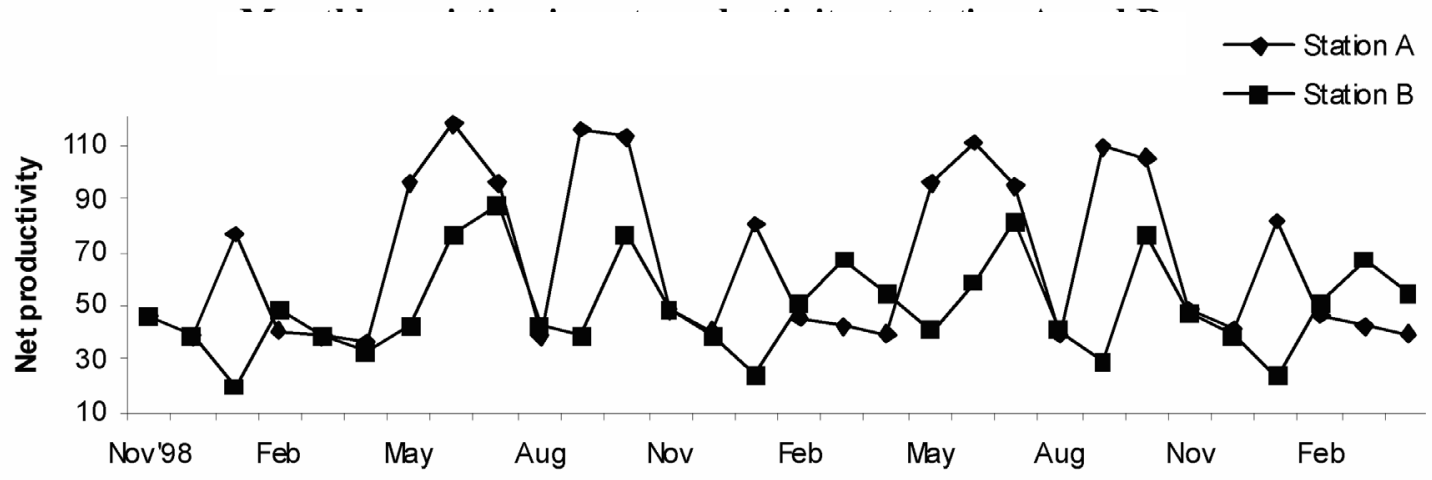

Figure 6. Monthly variation of net productivity at station $A$ and $B$

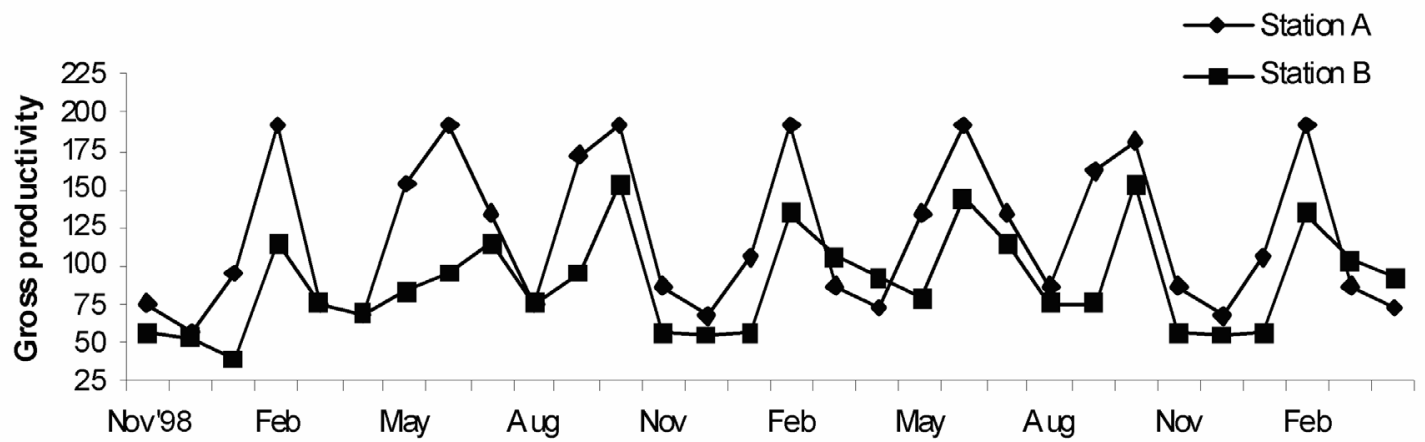

Figure 7. Monthly variation of gross productivity at station $A$ and $B$

An increase in the nitrate concentration during monsoon months was detected with respect to pre-monsoon (Fig. 10). The onset of south west monsoon was accompanied by a general rise in the nitrate level and the concentration of the nutrients was high during the monsoon months in Cochin estuary [17]. There was a net increase in nitrate concentration during monsoon and post monsoon and a decrease in pre-monsoon 


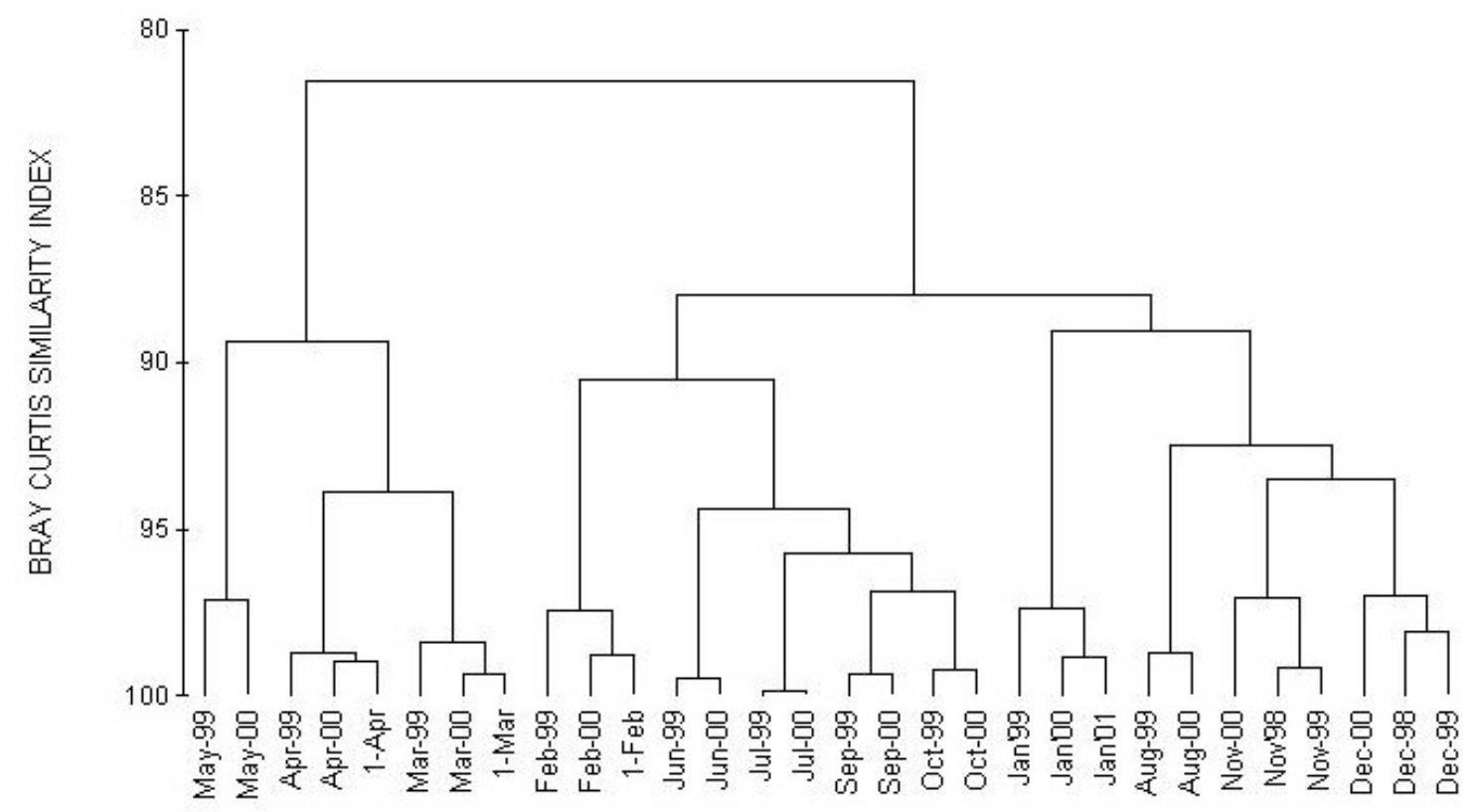

Figure 8. Dendrogram for months at Zone A (net productivity)

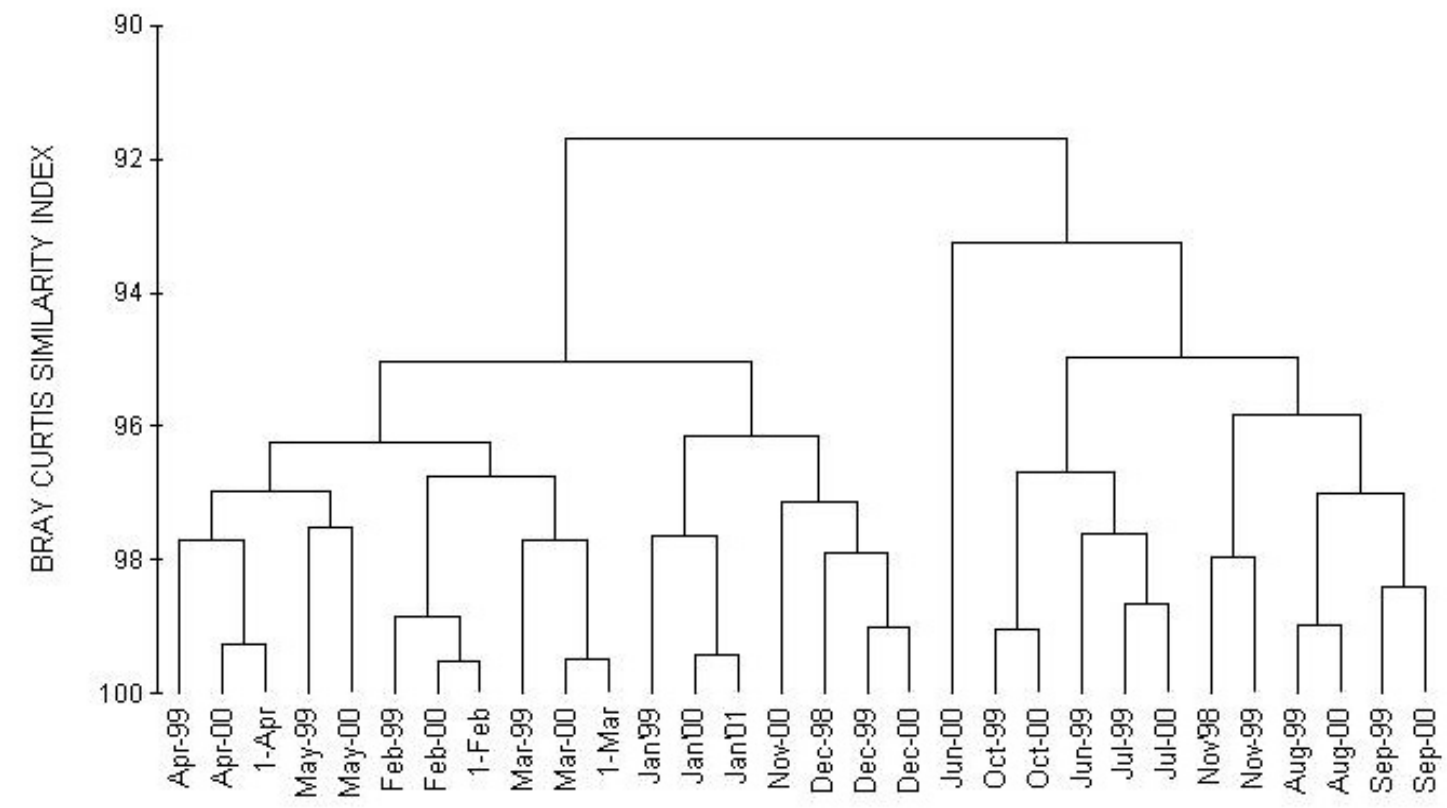

Figure 9. Dendrogram for months at Zone B (net productivity)

period; during monsoon and post monsoon there was net addition of nutrients and during pre-monsoon there was net removal [5].

Seasonal average of nitrite concentration was low during monsoon months (Fig. 11) and high nitrite concentration was noted at zone B and low at zone A; due to the influx of large volume of freshwater with low nutrient content, which is believed to diluted the estuarine waters considerably, resulting in the modified nutrient pattern [17]. 


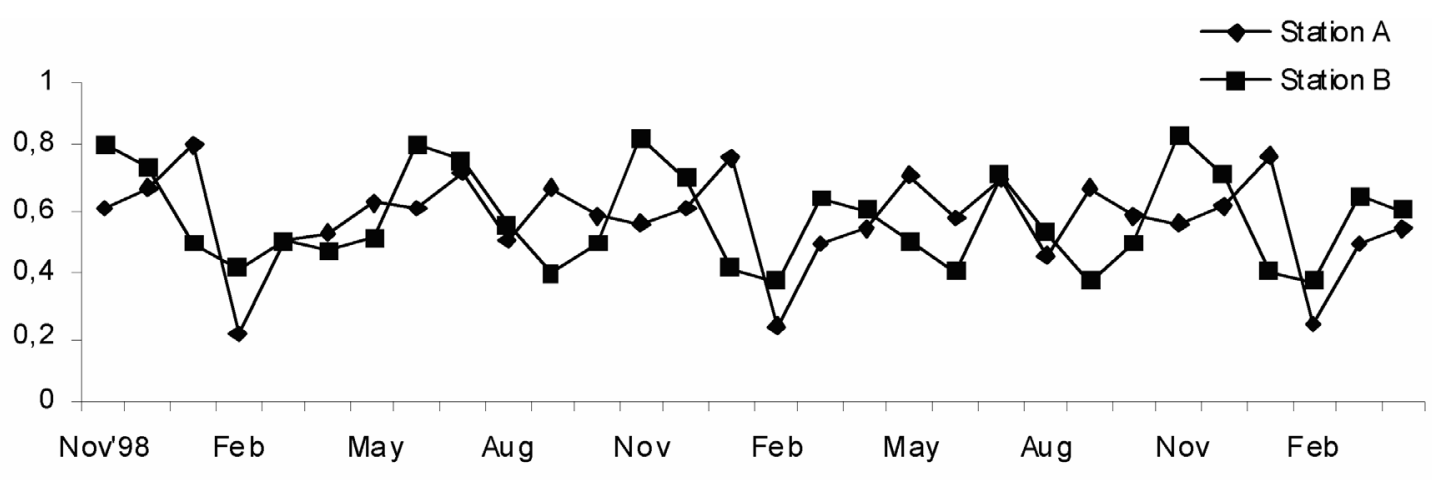

Figure 10. Monthly variation of net : gross productivity ratio at station $A$ and $B$

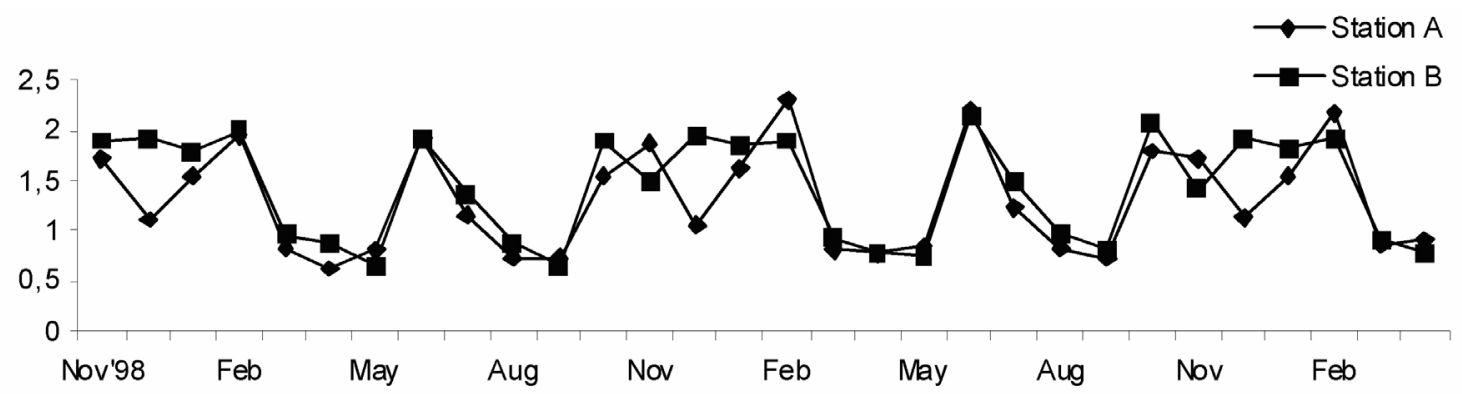

Figure 11. Monthly variation of nitrate concentration at station $A$ and $B$

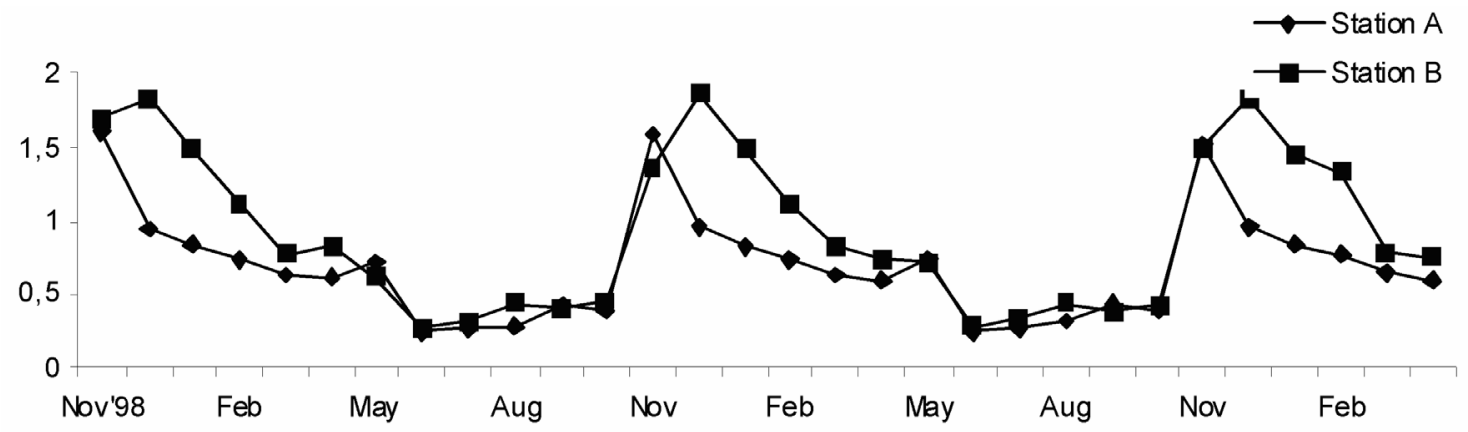

Figure 12. Monthly variation of nitrite concentration at station $A$ and $B$

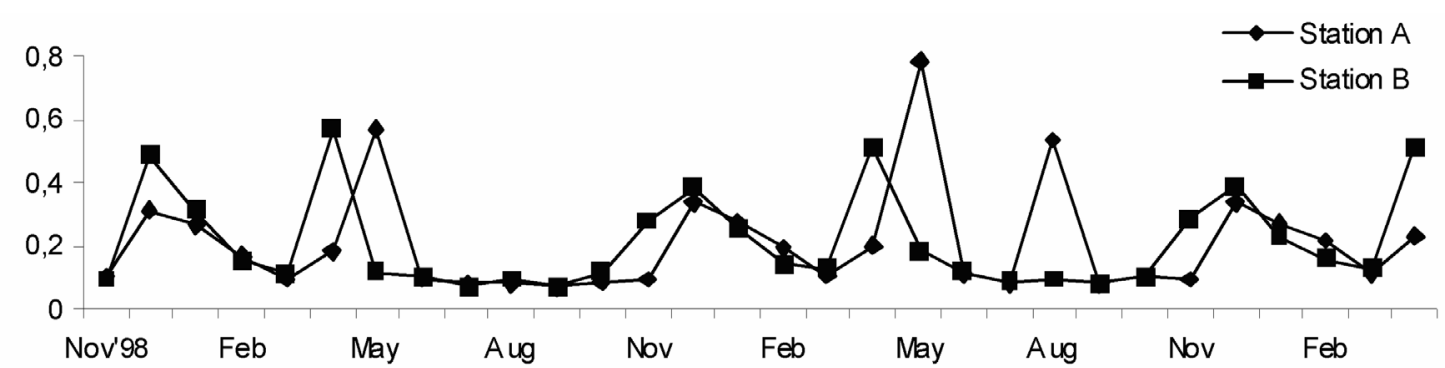

Figure 13. Monthly variation of nitrite concentration at station $A$ and $B$

Phosphate concentration was low during monsoon months (Fig. 12) which may be due to the dilution of estuarine water with rainwater. Higher concentration during summer months may be the liberation of phosphate from the bottom mud. Relatively high concentrations of phosphate during pre-monsoon and a sharp decrease in concentration 


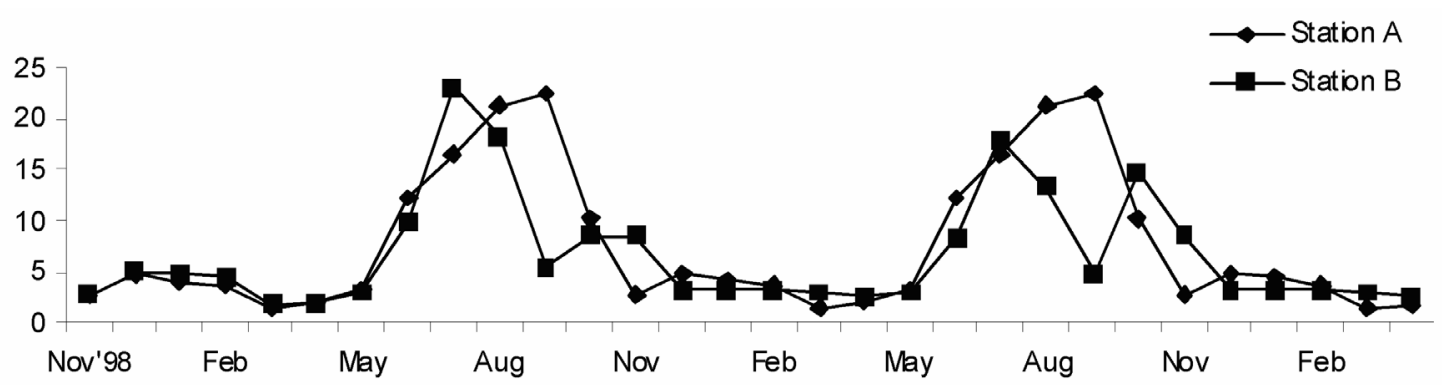

Figure 14. Monthly variation of silicate concentration at station $A$ and $B$

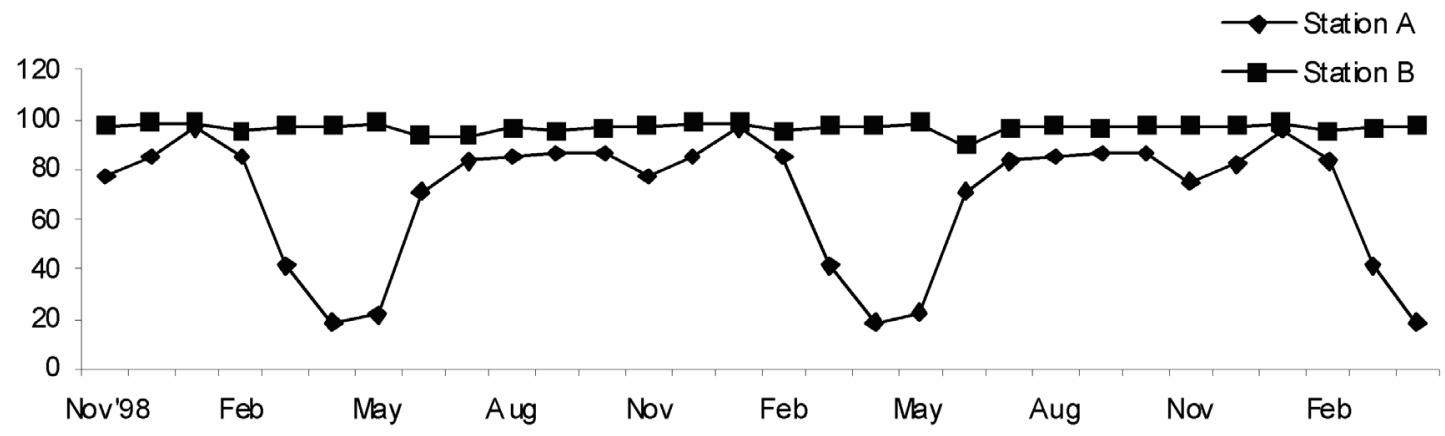

Figure 15. Monthly variation of $\%$ of sand at station $A$ and $B$

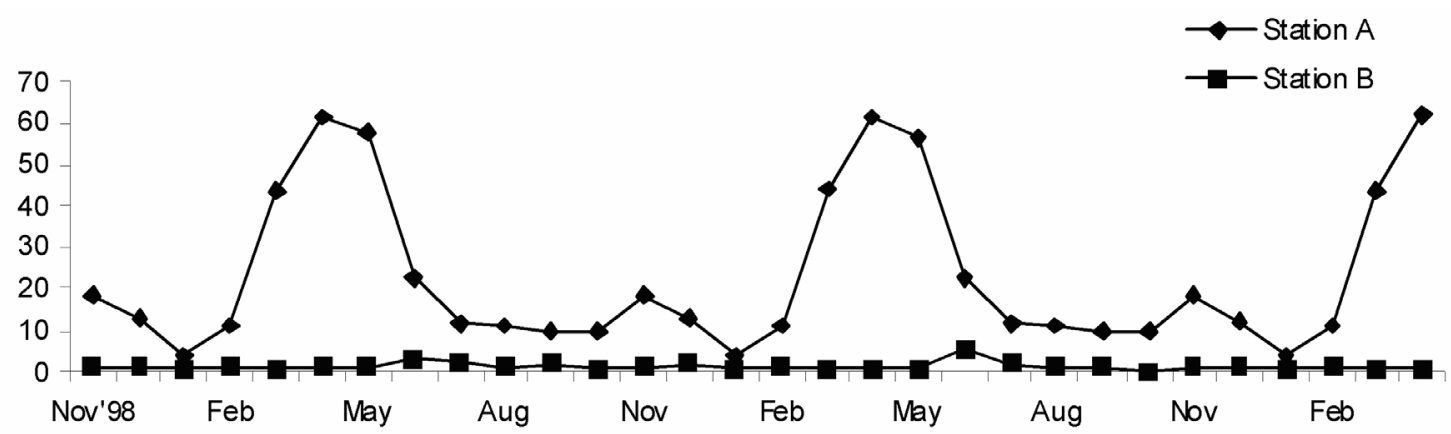

Figure 16. Monthly variation of $\%$ of silt at station $A$ and $B$

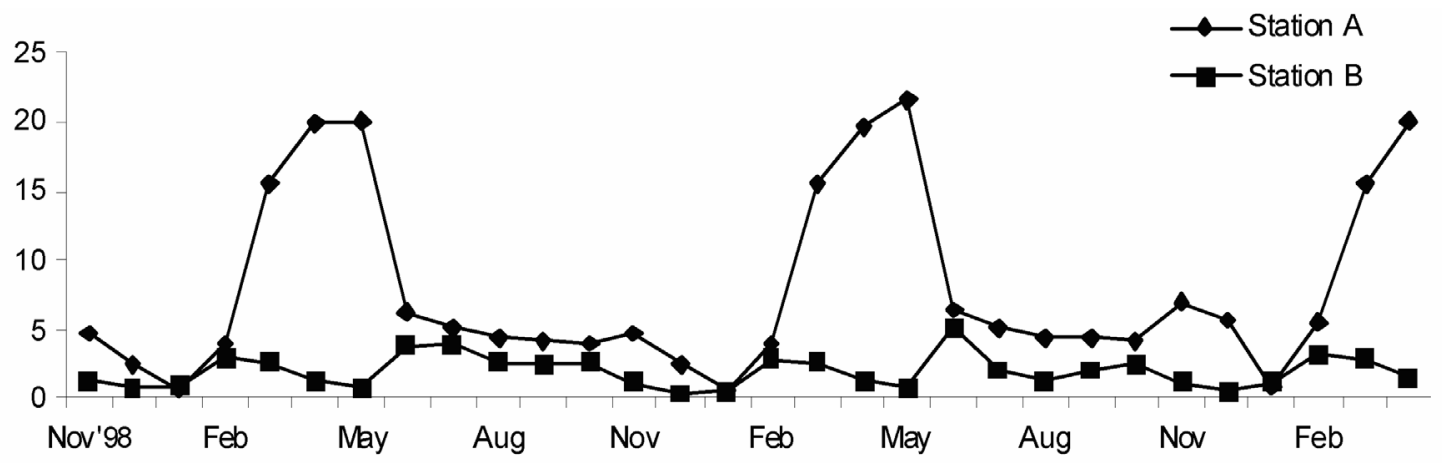

Figure 17. Monthly variation of $\%$ of clay at station $A$ and $B$

after reaching the peak; sudden break in monsoon and subsequent removal of phosphate from the ambient water by the silt brought into the estuary by heavy rain and utilization by algal population can be observed [13]. 


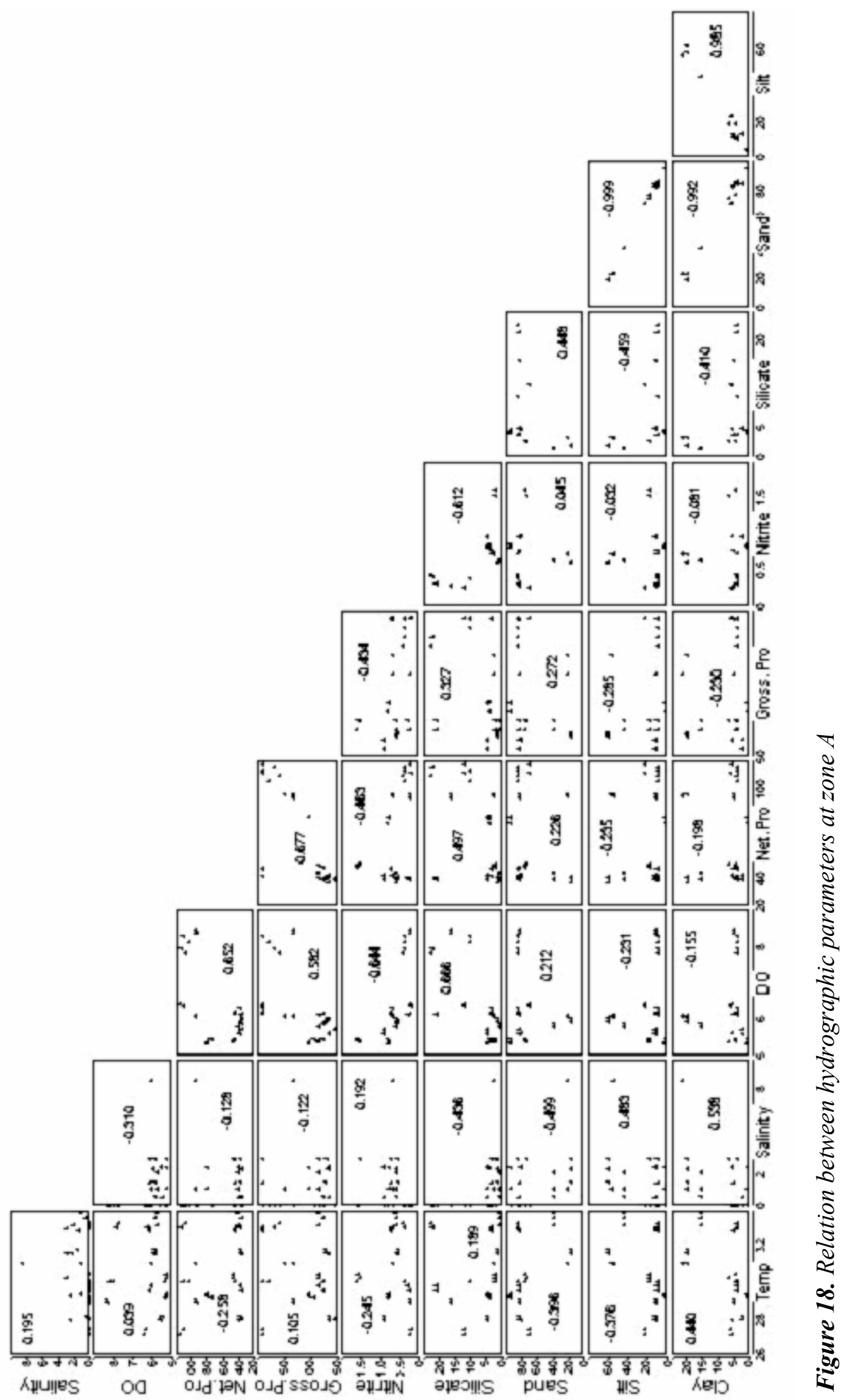


Considering the impact of bund the average dissolved silicate content was higher at zone A and lower at zone B (Fig. 13) in agreement with the fact that it is freshwater that brings dissolved silicate into the estuary [8]. High silicate concentration during monsoon months may be due to monsoon showers and resultant land run offs and lower during pre-monsoon may be due to the adsorbance of silicate by the suspended particles and co-precipitation with humic acid [8].

At zone A, from January to April there was an increase in the percentage of silt and clay and corresponding decrease in sand (Figs. 14-16). Closure of bund leads to the prevention of the current which results in the settlement of sediment particles at this point. At zone B the sediment was dominated by sand, the admixture of freshwater and saline water reduces the velocity of the transporting agent, leading to the deposition of coarser particles such as sand at the head of the estuary [19]. According to Vereyya \& Murthy [27] in the Cochin estuary the dominant sediment texture was sandy silt with high sand $(<30 \%)$ and low clay levels. But results of the present study have established that in zone A the major constituents were sand (19-97\%), silt (3-62\%) and clay (1-6\%). This drastic change in sediment texture has to be due the construction of Thannermukkom bund.

Bray-Curtis similarity analysis for the fourth root transformed data at zone A (Fig. 17) has divided the study period in to three distinct clusters containing the months: cluster 1 (May 1999, May 2000, April 1999, April 2000, April 2001, Mar 1999, Mar 2000, Mar 2001), 2 (Aug 1999, Aug 2000, June 1999, June 2000, July 1999, July 2000, Sept 1999, Sept 2000, Oct 1999, Oct 2000) and 3 (Jan 1999, Jan 2000, Jan 2001, Feb 1999, Feb 2000, Feb 2001, Dec 1998, Dec 1999, Dec 2000, Nov 2000, Nov 1998, Nov 1999). These months are linked at 93\% similarity in each cluster. At zone B (Plate 6) also it has given three distinct clusters, 1 (Apr 1999, Apr 2000, Apr 2001, May 1999, May 2000, Feb 1999, Feb 2000, Feb 2001, Mar 1999, Mar 2000, Mar 2001), 2 (Jan 1999, Jan 2000, Jan 2001, Nov 2000, Dec 1998, Dec 1999, Dec 2000) and 3 (Oct 1999, Oct 2000, June 1999, July 1999, July 2000, Nov 1998, Nov 1999, Aug 1999, Aug 2000, Sept 1999, Sept 2000) which are all interlinked within each cluster at similarity level $>96 \%$.

This grouping has occurred in a manner that at both zones cluster 1 is formed of months belonging to closed period (December to May) of the bund and cluster 2 by the months of opening period (June to November) of the bund and third cluster by the initial and final months of opened and closed period. This gives a clear-cut difference between closed and opened stages of the bund and leads to the confirmation that periodical opening and closing of the bund affects all the hydrographic parameters in similar fashion in each month in every year. It can be concluded that construction, existence and periodical opening and closing of the bund at Thannemukkom has been seriously deteriorating the ecology of the Cochin estuary especially in the southern part of the bund with respect to clam beds.

Acknowledgements. Author thanks Head, Dept. of Marine Biology, Microbiology and Biochemistry, School of Marine Sciences, Cochin University of Science and Technology for the permission rendered to carryout this work. Thanks are also due to personnel for their assistance in the fieldwork.

\section{REFERENCES}

[1] Arun, A.U. (2002): Biology, Experimental culture and toxicity studies of Villorita cyprinoids in Cochin Estuary. Ph.D thesis, Cochin University of Science and Technology.

[2] Bendschreider, K. \& Robinson, R.J. (1952): A new spectophotometric method for the determinationof nitrite insea water. - J. Marine Res. 11: 87.

[3] Beninger, P.G. \& Lucas, A. (1984): Seasonal variations in condition, reproductive activity, and gross biochemical composition of two species of adult clam reared in a common habitat. - J. Exp. Mar. Biol. Ecol. 79: 19-37. 
[4] Carver, R.E. (1971): Procedure in sedimentary petrology. Willey, New York, 653 pp.

[5] De Sousa, S.N. \& Sen Gupta, R.S.S. \& Rajagopal, M.D. (1981): Studies on nutrients of Mandovi and Zuari river systems. - Indian J. Mar. Sci. 10: 314-321.

[6] Galtsoff, P.S. (1964): The american oyster, Crassostrea virginica (Gmelin). - Fishery Bull. Fish. Wildl. Surve. U.S. 64: 1-480.

[7] Gopinathan, C.P. (1972): Seasonal abundance of phytoplankton in the Cochin back water. - J. Mar. Biol. Ass. India 14(2): 568-577.

[8] Gouda Rajashree \& Panigrahy, R.C. (1992): seasonal distribution and behaciour of silicate in the Rishikulya estuary (East coast of India.). - Indian J. Mar. Sci. 21: 111-115.

[9] Grasshoff, K., 1983. Methods of sea water analysis. In: Grasshoff, K., Ehrardt, M. \& Kremling, K. (eds): Chemie, pp. 31-139.

[10] Haridas, P., Madhu Pratap, M. \& Rao, T.S.S. (1973): Salinity, temperature, oxygen and zooplankton biomass of the backwaters from Cochin to Alleppey. - Indian J. Mar. Sci. 2: 94-102.

[11] Jaybal, R and M. Kalyani., 1986. Reproductive cycles of some bivalves from Vellar estuary,East coast of India. Indian.J. Mar. Sci., 15 : 59 - 60.

[12] Jeena T.S. (2002): State regulation and the possibilities of a collective action for the management of local-level common property resources: the case of cochin estuarine fisheries in Kerala, India. Paper submitted to Beijer Research Seminar on "Property Right and Environment Resource Management", May 28-30 2002.

[13] Joseph, P.S. (1974): Nutrient distribution in the Cochin Harbour and in its vicinity. Indian J. Mar. Sci. 3: 28-32.

[14] Koroleff, F. (1971): Determination of reactive silicate. - Indian J. Mar. Sci. 43.

[15] Kumaran, S. \& Rao, T.S.S. (1975): Phytoplankton distribution and abundance in the Cochin back waters during 1971-1972. - Bull. Dept. Mar. Sci. Univ. Cochin 7(4): 791-799.

[16] Kurian, C.V. (1972): Ecology of Benthos in a tropical Estuary. - Proc. Indian Natn. Sci. Acad. 38: 156-163.

[17] Lakshmanan, P.T., Shynamma, C.S., Balchand, A.N. \& Nambisan P.N.K. (1987): Distribution and variability of nutrients in Cochin back waters, Southwest coast of India. - Indian J. Mar. Sci. 16: 99-102.

[18] Modassir, Y. (1990): Ecology and production of benthic bivalve Meretrix casta (Chemnitz) in Mandovi estuary, Goa. - Indian J. Mar. Sci.19: 125-127.

[19] Mohan, P.M. (2000): Sediment transport mechanism in the Vellar estuary, east coast of India. - Indian J. Mar. Sci. 29: 27-31.

[20] Morris, J.C. \& Riley, J.P. (1963): A modified single solution method for the determination of phophate in natural waters. - Anal. Chim. Aeta 29: 272.

[21] Nair, B. (1989): Report of the expet committeeon marine fishery resources management in Kerala. A Report Submitted to Government of Kerala.

[22] Ramamirtham, C.P. \& Jayaraman, R. (1963): Some aspects of the hydrographical conditions of the backwaters around Willington island (Cochin). - J. Mar. Biol. Ass. India 5(2): 170-177.

[23] Strickland, J.D.H. \& Parsons, T.R. (1968): A manual of seawater analysis. - Fish. Res. Bd. Canada, 167.

[24] Strickland, I.D. \& Parsons, T.R. (1977): Practical handbook of sea water analysis. Bull. No.1967 (Fish Res. Bd. Canada, Ottawa), 203 pp.

[25] Thalikedkar, P.M., Mane, U.H. \& Nagabhushanam, R. (1976): Growth rate of the wedge clam, Donax cuneatus, at Mirgabay, Ratnagiri. - India J. Fish. 23(1-2): 183-193.

[26] Tinu, A.T. \& Robert, S.P. (1992): The role of environment in shell growth dynamics of the Asian clam Corbicula fluminea (Mollusca: Bivalvia). - Malacological Review 25: 109-117.

[27] Veerayya, M. \& Murty, P.S.N. (1974): Studies on the Sediments of Vembanad Lake, Kerala State: Part III. Distribution and Interpretation of Bottom Sediments. - Indian J. Mar. Sci. 3: 16-27. 